\title{
Collectanea Theologica 2020 Special Issue: A Word from the Editor-in-Chief
}

Ollectanea Theologica is one hundred years old. To celebrate
the jubilee year, the standard four issues are complemented
with a fifth one-an exhaustive special issue. Its contents include
English translations of selected papers published in our journal over
the last couple of years.

Thus, we would like to draw on the tradition of Collectanea Theologica. Though in principle published in Polish, it since the outset tried to present the results of Polish theological studies also internationally. Before World War II and in the post-war period, some articles in our journal were published in Latin, German, or French. Between 1975 and 1988, Collectanea Theologica published an annual special issue (fasciculus specialis), in which Polish authors published their works in foreign language versions, to facilitate more fruitful, bilateral dialogue with theology worldwide. These articles were in part translations of Polish texts published beforehand in the journal. Such special issues were also compiled in 1994, 1998, 1999, 2001, 2004, and 2007.

In the year of the centennial anniversary of the journal, we return to that tradition, publishing a special issue in English. The articles presented in it are variegated in their subject matter and form, which reflects the transformations of the journal editorship occurring in the recent years. As the issue is intended predominantly for foreign readers, we have decided not to publish it in print, limiting ourselves to the electronic edition. We are hoping that the texts presented in this issue will prove interesting for our readers, encouraging them 
to reflect upon and engage in debate with the theses put forth in its articles. In this way, we would like to add something to the treasury of theology in the world, bringing us all closer to a more profound knowledge of God.

Bartosz Adamczewski Editor-in-Chief 